\title{
INTERPERSONAL MEANING OF ADELE SONG LYRICS IN 21' ALBUM: THE STUDY OF SYSTEMIC FUNCTIONAL LINGUISTICS
}

\author{
Riska Ariska, Ria Nirwana and R. Yeni Dewi Cahyani. \\ English Department, Faculty of Letters, Al-Ghifari University, Jl. A.H. \\ Nasution-Sukamiskin no.247, Bandung, 40293, Indonesia \\ riska.ariescha@gmail.com
}

\begin{abstract}
Abstrak: Penelitian ini mengangkat interpersonal meaning dalam lirik lagu Adele di Album 21 nya. Objek penelitian ini adalah untuk mendiskripsikan makna dari lagu Adele berdasarkan makna interpersonal dengan menganalisis system mood dan untuk mendeskripsikan bagaimana pengaruh lagu Adele terhadap pendengar melalui makna interpersonal dengan menganalisis system modality. Bentuk penelitian ini mengguanakan descriptive qualitative method. Sumber data utama pada penilian ini adalah lirik lagu adele di album 21nya. Ada tiga lagu yang diteliti dalam penelitian ini. Hasil dari penelitian ini ada 144 data dalam 3 lirik lagu Adele. Data itu sendiri direalisasikan dengan system mood yang terbagi menjadi 100 data deklaratif, 27 data interogatif, dan 17 data imperative. Hasil data analisis ini menunjukkan bahwa Adele kebanyakan menggunakan deklaratif. Adele menggunakan deklaratif disetiap lagunya karena dia ingin berbagi kisahnya kepada pendengar melalui lagunya. Isi dari lirik lagu adalah tentang kisah cintanya. Selain itu, berdasarkan data yang telah dianalisis melalui modality, peneliti menemukan 67 data dalam lagu Adele. Data itu sendiri dibagi menjadi 1 data usualiti, 55 data obligation, dan 11 data inclination. Obligation terjadi ketika seseorang ingin meminta seseorang untuk melakukan sesuatu untuk orang lain. Artinya Adele menggunakan obligation untuk meminta pendengar untuk mengetahui sesuatu. Adele menggunakan obligation untuk mempengaruhi pendengar. Obligation digunakan Adele untuk mengungkapkan keinginnannya melalui lirik lagu kepada pendengar bahwa dia berharap kepada pasangannya. Adele ingin pendengar tahu bahwa kisah cintanya sungguh rumit.
\end{abstract}

Katakunci: makna, interpersonal, lirik, modality, Adele.

Abstract: This research examined the interpersonal meaning realized in the lyrics of Adele's album 21. The objectives of this research are to describe the meaning of Adele's song based on interpersonal meaning by analyzing on the mood system of Adele's song and to describe how Adele's song effect the listeners through interpersonal meaning by analyzing on modality. The design of the research was descriptive qualitative. The main source of data in this research were the lyrics in the Adele's album 21. There were three song lyrics that the researcher analyzed in this research. The results of data analysis there are 144 data in three Adele song lyrics. The data itself is realized 
by system of mood that divided into 100 data of declarative, 27 data of interrogative and 17 data of imperative. The result of analysis shows that Adele mostly used declarative. Adele used declarative in every song lyrics because Adele wanted to share her story to the listener by delivering her songs. The content of song lyrics are about her love story. Besides that, based on data that has been analyzed through modality, the researcher found 67 data in Adele's songs. The data itself divided into 1 data of usuality, 55 data of obligation and 11 data of inclination. In Adele's song, Adele mostly uses obligation. Obligation occurs when someone has ask to do something for others. It means Adele uses obligation to ask the listeners to know something. Adele uses obligation to effect the listener. Obligation used to Adele to express through song lyrics to the listeners for her wishes she has ask to her couple. Adele wants listeners to know that her love story is complicated.

Keywords: interpersonal, meaning, song, lyrics, modality, Adele.

\section{INTRODUCTION}

Language is a system of conventional spoken or written symbols used by people for communicating with each other. People need language to communicate, to interact and to get information from other people. Nowadays, people can speak with other through song, through song someone could convey his/her voice to many people by listening song. Currently, a lot of songs could express our feelings, such as songs with the theme of love, social, political, and others. Human as social beings, need other people to fulfill their needs, for this purpose, communication is one of important tools for humans to get their need. Human use language as communication tool. Language has some units that are used for expression or opinion.
In communication process, human being will deliver his/her messages by speaking or writing. Speaking is a communication form to deliver messages directly. There are speaker and hearer speaking to each other, while, writing is a communication form that requires media to convey the messages, such as, television, magazine, newspaper, etc. Furthermore, as a communication or interaction tool, language has some units that are used to express an idea or write something. Sometimes when a great idea come it possible become a worst idea, because he could not deliver his idea in language. Therefore all ideas, opinions, and all the works of the mind will not be known if they do not have a good language.

There are many media in which human beings may express and communicate their information, idea, thought, emotion, and desire by using language, our basic of communication (Griffee, 1995:4). Language is used by normal human beings and by no other 
species, of using a spoken or written utterance to represent mental phenomena or events. Most fundamentally, language is the association of speech sounds with thoughts, concepts, or image in the mind. The primary purpose of language is communication among persons (Encyclopedia Americana, 1991: 727). In the hand of artist, the information, idea, thought, emotions, and desire are expressed in poem, prose, painting, drama, film, and music.

Music is a tool of culture that is present in society as the construction of social reality as outlined in the form of song lyrics. At first, the requirement of song was used for the traditional ceremonies and rituals. Music is said to be language of emotions and the activity of listening to music is indeed a part of everyday life. If questioned about the song one would want to hear at any particular moment, one would surely pick a song that would be relevant to his mood. Musical aspects definitely play an important role in deciding the emotion of a song. Even so, most people are able to connect with the words of a song better than its musical features. In most cases, the words of the song are what truly express the emotions associated with the music, while the musical aspects are generally made to revolve around the lyrical theme.

Actually, music is not only music itself but also lyric. Throughthe lyric, the readers or listeners will know the topic of the song. Song is a term of music. A song contains music and lyric. It is also one of the forms of music, which uses language. Every song has its own special arrangement in music and lyric. It is the way to tell a language. It is used by human to tell something in different ways. Through the song, the singer wants to tell the listeners about the writer's feelings that come from his/her heart. There are songs that tell about sadness, happiness, love, social critique, etc. Songs speak to us directly about our experiences; they reassure us in our moments of trouble (Griffee, 1992: 4). It also tells something or someone's feeling that uses imaginative diction and rhyme. People almost hear songs every day; even the listeners can memorize the lyrics very well. It is very interesting to see how the composer plays with words and cords to convey the message, and it is very interesting to study or analyze something that people like very much.

The songs that show the writer's feeling can be heard from one of the phenomenal women singer, Adele. Adele began writing 21 in April 2009, when still involved in the relationship that subsequently inspired the record. Dissatisfied with once again portraying herself as the musical tragedian of her debut, she had intended to compose a more upbeat and contemporary followup. However, studio sessions ended prematurely due to a lack of inspiration. She resumed production immediately after the breakdown of her relationship, channeling her heartbreak and depression into her songs. Adele collaborated with various songwriters and producers, including Columbia Records co- president Rick Rubin, Paul Epworth, Ryan Tedder, Jim Abbiss, and Dan Wilson. 
(http://www.metrolyrics.com/adel ealbums-list.html).

This analysis is carried out based on Systemic Functional Linguistics (SFL) approach which is introduced by Halliday. It is different from any other theory of language. It interprets language as a system of meaning, accompanied by forms through which the meaning can be realized (Halliday, 1994: xiv).

This research focuses on the interpersonal relationship that can be seen through the interpersonal meaning realized on the song's lyrics. The researcher conducts a linguistic research on interpersonal meaning analysis in the lyrics of Adele album

21. People use interpersonal meaning in communicating his/her emotion, feeling, desire, etc. In Systemic Functional Linguistics theory, how the writer expresses his/her idea, emotion, feeling, etc. can be seen through the use of interpersonal meaning. Halliday (1985) states that interpersonal meaning is meaning as a form of action: the speaker or writer doing something to the listener or reader by means of language. Interpersonal meanings are meanings which express a speaker's attitudes and judgments. These are meanings for acting upon and with others. The elements of interpersonal meanings are Mood and Residue. Mood element carries the interpersonal functions of the clause and consists of Subject and Finite. The other element is called the Residue. Mood and Residue realizedin the texts or articles, such as a song lyric, newspaper, magazine, letter, science, speech, and many others. Many media serve knowledge and message or information either in spoken such as radio, music, song, television, etc. or in written like magazine, newspaper, book, etc.

Based on the background above the research was conducted in analyzing interpersonal meaning in the lyrics of Adele's album 21 under the title of Interpersonal Meaning of Adele Song Lyrics in 21' Album (A Study Based on Systemic Functional Linguistics). Here are some problem discussed in this research:

1. How are the interpersonal meaning in the song lyrics of Adele album 21?

2 How does Adele's song effect the listeners through interpersonal meaning?

From the statement of the problem above, the purposes of this research are:

1. To describe the interpersonal meaning in the song lyrics of Adele album 21.

2 To find out how Adele's song effects the listeners through interpersonal meaning.

\section{THEORITICAL FOUNDATION}

\section{Systemic Functional Linguistics}

Systemic Functional Linguistics (SFL) is a study of language which focuses on language as a resource of meaning. This theory is introduced by M.A.K Halliday by using discourse analysis. It views language primarily as a resource for exploring and understanding the meaning in 
discourse (Halliday, 1994: XIV). It is different from any other theory of language since it has both systematic and functional in itscharacteristic. Systemic theory is a theory of meaning as choice, by which a language or any other semiotic system is interpreted as networks of interlocking options (Halliday, 1985: XIV).

Interpersonal Meaning

According to Gerot and Wignell (1994:13), the interpersonal meanings are meanings which express a speaker's attitudes and judgments. These are meanings for acting upon and with others. Interpersonal meaning, according to Butt (2001:86) is one of the most basic interactive distinction is between using language to exchange information and using it to exchange goods and services.

\section{Mood Element}

In relation to the metalanguage that relevant to the language interaction, there are two elements that are mood and residue.

Mood

The mood system at the clause encodes the relationship between the participants in an interaction as well as the speakers or writer's attitude and comment. Included here, for example, are indicative, imperative, and interrogative instructions.
Mood consists of subject, finite, and/or mood adjunct (Eggins, 1994:154-169). The Subject is a nominal group while the Finite operator is part of a verbal group.

Residue

Residue consists of predicator, complement, and some adjuncts such as mood, polarity, comment, vocative or circumstantial adjunct (Eggins, 1994:154-169). Eggins (1994:161) suggest Residue as the part of the clause of which is somehow less essential to the arguability of the clause than is the Mood component. However, the Residue component can also contain a number of functional elements: a Predicator, one or more Complements, and any number of different types of Adjuncts (Eggins, 1994:161).

\section{Mood System}

Mood system is a system which describes the types of clauses which is being carried in a verbal interaction whether it is indicative (declarative, interrogative) or imperative. Mood structure is a clause structure which realizes an interpersonal meaning. The interpersonal meaning concerns the relationship or interaction among participants, which can be classified into two giving and demanding. These interactions related to the nature of commodity being exchanged: good and 
services or information. The mood structure, then, is used to see the semantic meaning of a clause whether it is proposition (giving or demanding information) and proposal (giving and demanding goods and services) (Santosa, 2003: 108).

Modality

The study of modality is useful for people to understand how they make meanings about interpersonal dimension such as their social status and role, and their attitudes and judgments. Meanwhile, Butt (2001: 113) uses the term of modality to refer to all positioning by speaker about possibility, usuality, typically, obviousness, obligation and inclination. It means Modality is used to refer how speakers signal probability, usuality, inclination and obligation. It is a system which allows people to modify prepositions or proposals as regards probability, usuality, inclination or obligation.

\section{Modalization}

Modalization consists of probability and usuality. Probability occurs when the speaker expresses judgment as to the likelihood or probability of something happening or being happened. For example: It might be a debt collector. Usuality occurs when the speaker expresses judgment as to the frequency with which something happen. For example: And a store always smells good. Each category of modalization is divided into three values or degrees. They are high, medium and low degree.

\section{Modulation}

Halliday (1985: 89) refers modulation as the way speakers express their judgments or attitudes about actions and events. When people interact and exchange goods and services one to another, their clause of communication takes the form of proposal. It has two types, inclination and obligation. Inclination represents the tendency of speakers in doing something, and the capability from his or her own feeling. For example: And I need to do it again. Obligation occurs when the speaker give command, suggestion, demand, and advice to the listener. For example: You should have read the fine print.

\section{METHODOLOGY}

This research uses descriptive qualitative method. The researcher of this study attempt to describe the interpersonal meaning in the lyrics of Adele album 21 that realized in the system of Mood and Modality without making any calculation or enumeration. According to Sutrisno Hadi (1983: 3) states that collecting the data, classifying the data, analyzing the data, interpreting the data, and finally drawing conclusion without making 
generalization carry out descriptive method. Narbuko and Achmadi (1997: 44) also state that a descriptive method is a research method which tries to give the solution of a problem based on the data. In this research, the researcher used indirect observation technique since she used video,Youtube, and Internet to get the song lyrics of Adele's songs. Then, scrutinized the songs and noted the lyrics.

This research used simple random sampling. According to Sugiyono (2013), simple random sampling is making member sample of the population of randomly regardless strata in a population.

\section{RESULT AND DISCUSSION}

The Interpersonal Meaning in the Song Lyrics of Adele Album 21

The interpersonal meanings in the transcripts were identified and analyzed. The analysis was concentrated on the analysis of Mood and Residue. Interpersonal meanings are meanings which express a speaker's attitudes and judgements. They are meanings for acting upon with others. Meanings are realized in wordings through what is called mood and modality. This meta- function is about the social world, especially the relationship between speaker and listener, and is concerned with clauses as exchange. The researcher draw the conclusion that the meaning Adele's songs based on interpersonal meaning can be seen through mood system.

The researcher have analyzed Adele's songs through mood system. The mood system itself consists of declarative, interrogative and imperative.

Data and Analysis of Declarative in Adele's songs

\section{Data 5}

I had no idea of the state we were in.

\begin{tabular}{|l|l|l|l|}
\hline I & Had & $\begin{array}{l}\text { no ideawe were } \\
\text { of } \\
\text { thein } \\
\text { tats }\end{array}$ \\
\hline S & F & C & A \\
\hline M & & R & \\
\hline
\end{tabular}

\section{DECLARATIVE}

In data 5, mood consists of the Subject and the Finite. Thus, in 'I had no idea of the state we were in', ' $I$ ' is Subject; meanwhile, had is Finite. 'no idea of the state' is complement. Meanwhile, 'we were $i^{\prime}$ is adjunct or more than correct called circumstantial adjunct. Admittedly, mood types in this clause is Declarative mood. Declarative clause is functioned as statements to give as much as possible information to the reader or listener. It is employed to give information to the listeners or readers about the condition of the song's writer.

Data 6

I know I have a fickle heart and bitterness. 


\section{DECLARATIVE}

In data 6, this clause, mood consists of subject ' $I$ ' and finite 'know'. Meanwhile residue consists of complement 'I have a fickle heart and bitterness' is second sentence. Moreover, mood types in this clause is Declarative mood. Declarative clauses are functioned as statements to give as much as possible information to the reader or listener. It is employed to give information to the listeners or readers about the condition of the song's writer. The declarative clauses show that the clauses of the text are giving or demanding information to the listeners or readers. Therefore, the writer is called an informant of the information whereas the listeners or readers are the receiver of the information.

Data 10

The reason you loved me before

\begin{tabular}{|l|l|l|}
\hline The reaso n you & Love d & Me befor \\
& & e \\
\hline S & F & A \\
\hline M & & R \\
\hline
\end{tabular}

DECLARATIVE

In data 10, the Mood element includes Subject 'the reason you' and Finite 'loved'. In this clause, Finite is fused with the Predicator. In 'the reason you loved before', the Finite appears to be missing, but is in fact fused with the Predicator 'love' (loved
= Finite: 'did' + 'Predicator: 'love'). While the Residue consists of Adjunct 'me before'. In addition, mood types in this clause is Declarative mood. Declarative clause is functioned as statements to give as much as possible information to the reader or listener. It is employed to

give information to the listeners or readers about the condition of the song's writer.

Based on the research, the data that the researcher found is 100 data. Adele uses declarative because her position and the listeners is the same. So, the sentence that used to Adele is declarative. The data of declarative mostly about Adele's desire. It means Adele has a desire to share her story to the listener by delivering her songs that realized through declarative.

Data and Analysis of Interrogative in Adele's Songs Data 1

Don't you remember?

\begin{tabular}{|l|l|l|}
\hline Don't & You & $\begin{array}{l}\text { Rememb } \\
\text { er }\end{array}$ \\
\hline $\mathrm{F}$ & $\mathrm{S}$ & $\mathrm{P}$ \\
\hline $\mathrm{M}$ & & $\mathrm{R}$ \\
\hline
\end{tabular}

INTERROGATIVE

In data 1 , the analysis of interpersonal meaning in this clause deals with two components that are Mood element and Residue element of the clause. The Mood element includes Finites 'don' $t$ ' and subject 'you'. While the Residue 
consists of predicator 'remember'. On the other hand, Mood types in this clause is Interrogative mood. The clauses express the writer of the song's questions about his condition. The interrogative clause is used to make the song more acceptable and easier to involve in this song.

Data 12

When was the last time you thought of me?

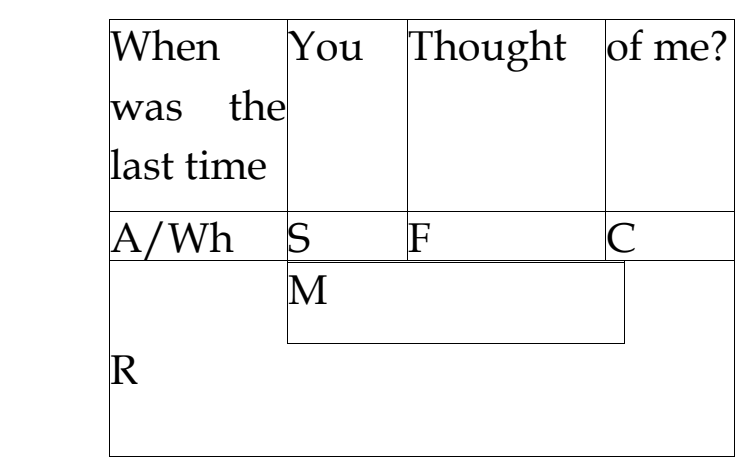

\section{INTERROGATIVE}

In data 12, this clause 'When was the last time you thought of me?'. The mood consists of finite is "thought" then subject is "you". Meanwhile the residue consists of adjunct or can be called circumstantial adjunct is "when" complement is "of me". Anyway, Mood types in this clause is Interrogative mood. The clauses express the writer of the song's questions about his condition. The interrogative clause is used to make the song more acceptable and easier to involve in this song.

Data 89

If this ain't love, then what is?

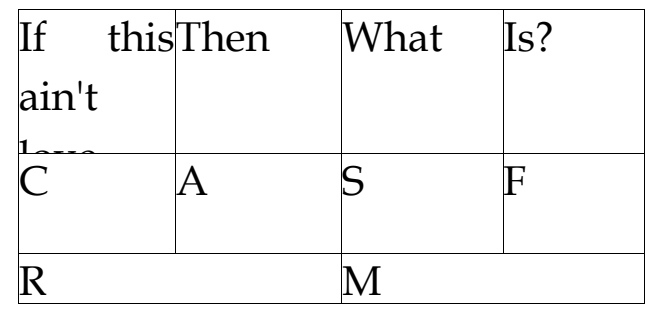

INTERROGATIVE

In data 89 , the analysis of interpersonal meaning in this clause deals with two components that are Mood element and Residue element of the clause. The Mood element includes Finites is 'is' and subject is ' $w$ hat'. While the Residue consists of adjunct or can be called conjunctive adjunct is 'then', after that complement 'if this ain't love.' Moreover, Mood types in this clause is Interrogative mood. The clauses express the writer of the song's questions about his condition. The interrogative clause is used to make the song more acceptable and easier to involve in this song.

Based on data that the researcher have analyzed, Adele only twenty seven use interrogative in her songs. It means, Adele's position is the recipient of the information and listeners as the provider of information.

Data and Analysis of Imperative Adele's Songs

\section{Data 29}

Baby, please remember me once more 


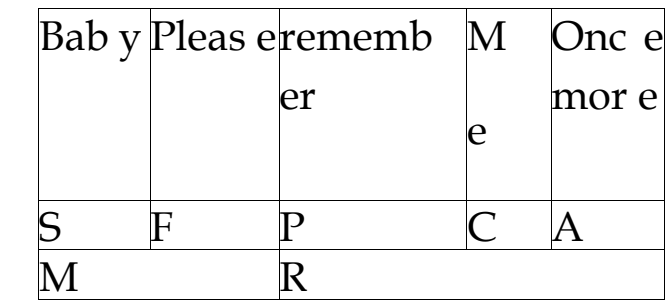

IMPERATIVE

In data 29, the analysis of interpersonal meaning in this clause deals with two components that are Mood element and Residue element of the clause. The Mood element includes Finites 'please' and subject 'baby'. While the Residue consists of predicator 'remember', after that complement ' $m e$ ' the last adjunct or circumstantial adjunct 'once more'. Therefore, mood types in this clause is Imperative mood. The Imperative Mood used to convey a command. It appeals the listeners or readers to follow the writer's instruction. Imperative clause express directives, such as orders, instructions, requests, invitations etc.

Data 50

Let me stay here for just one more night

\begin{tabular}{|l|l|l|l|}
\hline $\begin{array}{l}\text { Let } \\
\text { me }\end{array}$ & Stay & Here & $\begin{array}{l}\text { for just } \\
\text { one } \\
\text { more } \\
\text { night }\end{array}$ \\
\hline S & F & A & C \\
\hline M & R \\
\hline
\end{tabular}

IMPERATIVE

In data 50, mood consists of the Subject and the Finite. Thus, in 'Let me stay here for just one more night', 'let me' is Subject; meanwhile, stay is Finite. Meanwhile, residue consists of adjunct and complement. 'here' is adjunct or more than correct called circumstantial adjunct. 'for just one more night' is complement. Moreover, Mood types in this clause is Imperative mood. The Imperative Mood used to convey a command. It appeals the listeners or readers to follow the writer's instruction. Imperative clause express directives, such as orders, instructions, requests, invitations etc.

Based on data that the researcher have analyzed, the researcher found 17 data of imperative. In Adele's songs, Adele mostly uses imperative to express instruction. Adele not much uses imperative in her songs because Adele's position is the same or parallel with the listener. So, the sentence used is imperative.

In the three Adele's songs, the researcher found 144 data. The table below can explain how the meaning Adele's songs based on mood system.

\begin{tabular}{|l|l|}
\multicolumn{1}{|c|}{ The Mood System in Adele's } \\
songs
\end{tabular}

Table 4.19 Analysis of The Mood System

According to the table above, the most dominant in the mood system is declarative. The meaning Adele's songs based on interpersonal meaning can be 
seen from the way Adele builds a pattern of communication with listeners through songs. The sentence used in every lyrics of Adele songs is declarative. It indicates Adele positions herself same with the level of the listeners.

The Effects of Adele's Songs to the Listeners through Interpersonal Meaning

In this discussion, the researcher uses modality to find out how does Adele's songs effects the listeners. As stated Gerot and Wignell, interpersonal meanings are meanings which express a speaker $\mathrm{s}$ attitudes and judgments. The researcher uses modality because modality is a standard of the speaker's judgment through her songs. It means modality is used to refer how speaker/singer signal probability, usuallity, inclination and obligation. It is a system which allows people to modify prepositions or proposals as regards probability, usuallity, inclination or obligation. The study of modality is useful for people to understand how they make meanings about interpersonal dimension such as their social status and role, and their attitudes and judgments. In Adele's songs, the researcher found indicates that Adele's songs effects the listeners through modality. Modality itself divided into two parts. As stated Halliday, there are two kinds of modality; modalization and modulation. Each of those two types is also divided into two types. The modalization is divided into probability and usuallity, while modulation is divided into inclination and obligation. The two categories of modalization and modulation have three values or degrees each. They are high, medium and low.

\section{Modalization}

Modalization consists of probability and usuality. Probability occurs when the speaker expresses judgment as to the likelihood or probability of something happening or being happened. Meanwhile, usuality occurs when the speaker expresses judgment as to the frequency with which something happen. Each category of modalization is divided into three values or degrees. They are high, medium and low degree.

Probability

In Adele's songs, the data that has been the researchers analyzed showed that none of them indicated that Adele used probability to influence audiences. It means Adele cannot states a condition or something that will happen in the future.

\section{Usuallity}

The researcher only one found data in Adele's songs. The data itself indicates 
the medium level. It means, the medium level itself expresses something is done quite routine by the speakers in the statements. The data is explained by the table below:

The Medium Level of

\section{Data 4}

I often think about where I went



USUALITY

In data 4, the word 'always' indicates the high degree of usuality. Usuality itself is part of modalization. Usuality occurs when the speaker expresses judgment as to the frequency with which something happen In this statement, Adele gives the information and explained to the audiences that she often think about her mistakes.

\section{Modulation}

Modulation deals with the expression of asking, directing or expression of our willingness to get somebody to do something. These can be realized into asking for someone, offering declarative statement, advice statement, or even direct imperative statement. So, when people interact and exchange goods and services one to another, their clause of communication takes the form of proposal. It has two types, inclination and obligation. Inclination represents the tendency of speakers in doing something, and the capability from his or her own feeling. Meanwhile, obligation occurs when the speaker give command, suggestion, demand, and advice to the listener. Each category of modulation is divided into three values or degrees. They are high, medium and low degree.

Inclination

The data of inclination itself divided three levels but the researcher only one level of inclination in Adele's songs. The data itself is low level. The researcher found 11 of inclination data in Adele's songs. Explained of 1 data of inclination is explained by table below:

The Low Level of Inclination

Data 13

I was a child then but now I'm willing to learn 


\begin{tabular}{|l|l|l|l|l|}
\hline I & Was & $\begin{array}{l}\text { A } \\
\text { chil } \\
\text { d }\end{array}$ & $\begin{array}{l}\text { The } \\
\text { n } \\
\text { but }\end{array}$ & $\begin{array}{l}\text { I'm } \\
\text { willin } \\
\text { g to }\end{array}$ \\
\hline S & F & C & A & C \\
\hline M & & R & \\
\hline
\end{tabular}

\section{INCLINATION}

In data 13, the word 'willing' indicates the low degree of obligation. The low degree of obligation indicates the speaker's permission or asking for something to the listener. It also indicates the ability of the speaker of doing something. Obligation occurs when the speaker give command, suggestion, demand, and advice to the listener. In this statement, the word 'willing' explained about Adele want to learn.

Data 33

I'm willing to take the risk

\begin{tabular}{|c|l|l|l|}
\hline I & Am & $\begin{array}{l}\text { Willin } \\
\mathrm{g}\end{array}$ & $\begin{array}{l}\text { to } \\
\text { take } \\
\text { the }\end{array}$ \\
\hline $\mathrm{S}$ & $\mathrm{F}$ & $\mathrm{P}$ & $\mathrm{C}$ \\
\hline $\mathrm{M}$ & $\mathrm{R}$ & \\
\hline
\end{tabular}

\section{INCLINATION}

In data 33, the word 'willing' represents the medium degree of inclination. Inclination itself is part of modulation. Inclination occurs when someone has desire to do something for others. In this clause, the word 'willing' indicates an act for something. It is clear that the listeners, Adele gives the information to the listeners that she will take whatever the risk.

\section{Obligation}

The data of obligation divided three levels but the researcher found two level of obligation in Adele's songs. The data are medium and low level. The researcher found 55 of obligation data in Adele's songs. Example of two data represent medium and low of obligation are explained by table below:

The Medium Level of Obligation

Data 3

When will I see you again?

\begin{tabular}{|l|c|l|l|}
\hline When & Will & I & $\begin{array}{l}\text { You } \\
\text { again? }\end{array}$ \\
\hline A/Wh & F & S & C \\
\hline
\end{tabular}

\section{OBLIGATION}

In data 3 , The modality of the Modal Finite 'will' could be analyzed as expressing certainty with some impression of futurity. The word 'will' indicates the medium degree of obligation. Obligation itself is part of modulation. Obligation occurs when the speaker give command, suggestion, demand, and advice to the listener. The medium degree of modality 'will' further confirm that more actions will be definitely taken in the future. It means, 'will' here is used by Adele to hope her boyfriend to meet again.

The Low Level of Obligation 
Data 12

So I can tell you that I was wrong

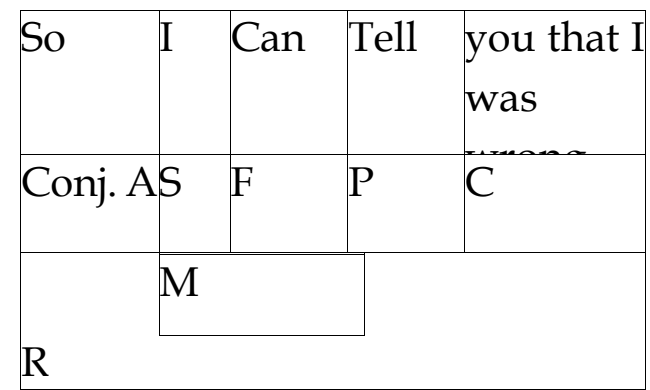

OBLIGATION

In data 12, the word 'can' indicates the low degree of obligation. The low degree of obligation indicates the speaker's permission or asking for something to the listener. It also indicates the ability of the speaker of doing something. Obligation occurs when the speaker give command, suggestion, demand, and advice to the listener. In this statement, the word 'can' explained about Adele mistake.

The data that researcher have found in three of Adele's songs are 67 data. The table below can explain 67 data that researcher have found:

Table 4.20 Analysis of Modality System



From the table above the researcher cannot found probability. There is no indicated that Adele used probability to influence the audiences. It means Adele cannot states a condition or something that will happen in the future.

Meanwhile, the researcher found only one data of usuallity. The data itself is medium level. Usuality occurs when the speaker expresses judgment as to the frequency with which something happen. Adele gives the information and explained to the audiences that she often think about her mistakes.

Besides that, the researcher found 55 data of obligation. The data of obligation divided into two levels. There are 43 data represents medium, and 12 data represents low. Adele uses 1 low level of obligation at the song "I'll be waiting" and 11 low level of obligation at the song "he won't go". The low level of obligation occurs when the obligation is indicated by the weak statements. It means, Adele's songs effects the listeners with weak lyrics.

Nevertheless, Adele uses 43 the medium level of obligation. Adele uses 3 medium level of obligation at the song "don't you remember?", 20 medium level of obligation at the song "I'll be waiting" and 20 medium level of obligation at the song "he won't go". The medium level of obligation used when someone asks someone else to do something in statement that is more 
flexible. It means, Adele asks to the listeners or her couple to do something that is more flexible. Adele gives the statement that is more flexible to the listeners.

On the other hand, based on the data above, the researcher found 11 data in three Adele's songs. The inclination itself is basically divided into three levels but in the Adele's songs the researcher only found one level. The data itself is low level. Adele uses 1 low level of inclination at the song "I'll be waiting" and 10 low level of inclination at the song "he won't go". The low level of inclination shows someone's desire in the weak statements. Mostly, it is indicated by willing, and other expressions that show willingness. In Adele's songs, Adele uses the low level in the two her songs. It means, Adele expressed her desire in the two of her songs.

\section{CONCLUSIONS}

Based on the analysis of the interpersonal meaning in the lyrics of Adele album 21', two conclusions can be drawn as follows:

Based on the analysis in the previous chapter, the meaning Adele's songs based on interpersonal meaning can be seen from the way Adele builds a pattern of communication with listeners through songs. The sentence used in every lyrics of Adele songs is declarative. It indicates Adele positions himself same with the level of the listeners. In the three Adele's songs there are 144 data. Every lyrics divided into: lyric one (don't you remember?) declarative 12, interrogative 11 and imperative 7. After that lyric two (I'll be waiting) declarative 38 , interrogative 0 and imperative 7 . And the last lyric (he won't go) declarative 50, interrogative 16 and imperative 3 . Adele mostly uses declarative in every song lyrics because Adele wanted to share her story to the listener by delivering her songs. The content of lyric which is shared is mostly about her love story.

The effect of Adele's songs to the listeners through interpersonal meaning can be seen from system modality. The researcher uses modality because modality is a standard of the speaker/singer judgment through her songs. According to Butt (2011:113) the term of modality is used refer to all positioning by the speaker about probability, usuality, obligation and inclination. It means modality is used refer how speaker/singer signal probability, usuality, inclination and obligation.in Adele's song lyrics the researcher found 67 data. The 67 data itself divided into: lyric one (don't you remember?) usuality 1 data, obligation 3 data. After that lyric two (I'll be waiting) obligation 21 data, inclination 1 data. And the last lyric (he won't go) obligation 31 data, inclination 10 data. 
The researcher can't found probability in Adele's songs. It clears the most dominant in Adele's songs is obligation.

Adele uses the medium level of usuality. Adele uses the word "often" in the first song lyric "don't you remember?" It means Adele effect the listeners with expresses something is done quite routine. Furthermore, in the second and last lyrics "I'll be waiting and "He won't go" Adele uses the low level of inclination. Adele uses the word "willing". It means Adele effect the listeners with shows she's desire in the weak statement. Nevertheless, from all the song lyrics Adele mostly uses the word "will' in medium level of obligation. Adele strongly effect the listeners through obligation. As the researcher explained before obligation occurs when someone has ask to do something for others. It means Adele uses obligation to effect the listeners. Obligation used to Adele to express through song lyrics to the listeners for her wishes she has ask to her couple. Adele wants listeners to know that her love story is complicated. 


\section{BIBLIOGRAPHY}

Printed References

Gerot, L. and Wignell, P. 1995. Making Sense of Functional. Sydney, Australia. Antipodean Educational Enterprise.

Butt, d, (et. al.). 1995. Using Functional Grammar. Sydney: National Centre for English Language, Teaching and Research.

Arikunto, S. 2002. Prosedur Penelitian: Suatu Pendekatan Praktek. Jakarta: Rineka Cipta.

Encyclopedia Americana vol. 16. 1991. Connecticut: Grolier Incorporated. Griffee, DT. .1992. Songs in Action. UK: Phoenix ELT.

Halliday, M.A.K. and Matthiessen, C. 2004. An Introduction to Functional Grammar. New York: Edward Arnold.

(2002). On grammar (edited by Jonathan J.Webster). London:

Continuum.

Eggins, S. 1994. An Introduction to Systemic Functional Linguistucs. London: Pinter Publisher Ltd.

Hyland, K. 2004. Genre and Second Language Writing. Michigan: University of Michigan Press.

Narbuko, Cholid, \& Abu Achmadi. 1997. Metodologi Penelitian. Jakarta: Bumi Aksara.

Santosa, R. 2003. Semiotika Sosial. Surabaya: Pustaka Eureka.

Subroto, E. 1992. Pengantar Metode Penelitian Linguistik Struktural. Surakarta: Sebelas Maret University Press.

Wiersma, W. 1995. Research Method in Education: An Introduction (6th Ed.).

Boston: Allyn and Bacon.

Moleong, LJ. 1990. Metodologi Penelitian Kualitatif. Bandung: Remaja Rosdakarya.

Schoenberg, 1995. Introducing Functional Grammar. Beijing: Foreign Language Teaching and Research Press.

Meyer, 1997. The Theory of Functional Grammar Complex and Derived Constructions. Berlin \& New York:Mouton de Gruyter 
Eastwood, J.2011. Oxford Guide to English Grammar. Walton: Oxford University Press

Putu Ayu, 2012. Methodology Research. Yogyakarta: Yayasan Penerbitan Fakultas Psikologi, Universitas Gadjah Mada.

Machlis, J. 1955. The Enjoyment of Music. US: The Vail-Ballou Press.

Hadi, S. 1983. Methodology Research. Yogyakarta: Yayasan Penerbitan Fakultas Psikologi, Universitas Gadjah Mada.

Echols, John M. Dan Hasan Saddily. 1996. Kamus Inggris Indonesia. Jakarta: PT. Gramedia Pustaka Utama.

------, 1994. Kamus Indonesia Inggris. Edisi Ketiga. Jakarta: PT. Gramedia Pustaka Utama. Lyons, John. Linguistics. Cambridge: Cambridge University Press, 1979. Arikunto, S. 2002. Prosedur Penelitian: Suatu Pendekatan Praktek. Jakarta: Rineka Cipta. Bloor, Thomas and Bloor, Meriel. 2004. The Functional Analysis of English. London:

Butt, d, (et. al.). 1995. Using Functional Grammar. Sydney: National Centre for English Language, Teaching and Research.

Buttt, D., Fahey, R., Feez, S. 2003. Using Functional Grammar-- An Explorer's Guide. Sydney: National Centre for English Language Teaching and Research.

Derewianka, Beverly. 1990. Exploring How Texts Work. ....?

Deterding, David and Poedjosoedaro, Gloria. 2001. English Grammar. New York: Routledge.

Eggins, S. 1994. An Introduction to Systemic Functional Linguistics. London: Pinter Publishers Ltd.

Eggins, S. (2010) An Introduction to Systemic Functional Grammar. London: Continuum. Gerot, L. And Wignell, P. 1994. Making Sense of Functional Grammar. Sidney Antipodean

Educational Enterprise (AEE).

Hadi, S. 1983. Methodology Research. Yogyakarta: Yayasan Penerbitan Fakultas Psikologi, Universitas Gadjah Mada.

Halliday, M.A.K. 1985. An Introduction to Functional Grammar. London: Edward Arnold Inc. 
Halliday, M.A.K. 1994. An Introduction to Functional Grammar (second edition) London: Edward Arnold Inc.

Halliday, M.A.K. 2002. An Introduction to Functional Grammar. Beijing: Foreign Language.

White, P. R. R. 2000. Functional Grammar. Birmingham: University of Birmingham.

Young, L., \& Harrison, C. 2004. Systemic functional linguistics and critical discourse analysis. London: Continuum.

Yule, G. (2010) The Study of Language (4th Ed). Cambridge: New York.

Electronic References

“21' Album” http://www.amazon.com/21-Adele/dp/B000FVQYYK Data retrieved On February, 15th 2018. 06.17 p.m.

"Adele" http://www. http:/ / adele.mu/news.htm Data retrieved on February, 15th 2018. 06:30 p.m

“Adele's Song Lyrics 2011." http:/ / www.metrolyrics.com/adele-albums-list.html Data retrieved on February, 15th 2018. 04:01 